\title{
Islam and Constitutions
}

\author{
Tengku Ahmad Hazri *
}

Across the Muslim world, constitutions frequently make reference to Islam. These references assume various forms. In some constitutions, Islam is declared as a state religion, official religion, or something similar, such as in Malaysia's Federal Constitution, which proclaims Islam to be "the religion of the Federation." In others (Egypt, Tunisia, Libya), the Sharia is promulgated as a source-if not 'the' source - of legislation. Yet others (Iraq, Afghanistan) include 'repugnancy clauses', i.e. clauses declaring laws that run contrary to Sharia to be invalid, null and void. Still others require the head of state or government to be a Muslim (e.g. Syria). The various ways in which Islam is incorporated into these constitutions reveals the centrality of religion to public life in most Muslim societies. But they also point to another important aspect, namely the negotiation of Islam and modernity. This is a recurrent leitmotif that runs throughout the constitutional history of the modern Islamic world.

Contrary to some claims, these provisions do not fall exclusively under the rubric of identity politics. On the contrary, these constitutions merely seek to capture the prominent role of Islam in the community. In this regard, the failure of formal state institutions to incorporate such demands has witnessed religious institutions arising outside the formal state framework, which weakens state-building initiatives and complicates nation-building agendas, thereby compromising the legitimacy of the state. A good example of this failure is Egypt under Gemal Nasser, whose presidential agenda veered towards socialism and Pan-Arabism, relegating Islamism to the background. Indeed, he abolished the Religious and Sharia Courts, seeing separate family courts as a relic of Ottoman colonialism that had to be done away with. His successor, Anwar Sadat, initially sought to pursue the same path, only later deciding to co-opt Islamic institutions. Thus, it was under Sadat that the constitution adopted Article 2, proclaiming Sharia to be 'a' major source of legislation.

Such constitutional references to Islam were entrenched for several reasons, including: to cement the identity of the people and state; to create continuity with the prevailing laws, beliefs and customs of the community; as a means of legitimising the government; and in recognition of the people's autonomy. Very often, however, the task of creating these provisions proved to be very delicate, as the state pursued multiple, often competing objectives at the same time. For example, the quest for a strong civic community had to be balanced 
with respecting the traditional identity of that community. Moreover, with regards to nation-building, communities had never before felt the need to neatly separate and compartmentalise their different identities, including the ethnic and religious. Instead, they embraced the reality of the interaction between those norms. Thus, in many societies, belonging to a religious community was often conflated with belonging to an ethnic community. In Russia, for example, Tatar identity became inseparable from being a Muslim, as did being a Tajik or Uzbek in Central Asia.

Turkey's relative stability and impressive economic performance has been attributed by some commentators to the success of its secular commitment, as outlined in its constitution. Yet Turkey is not the only country to pursue a constitutionally secular path; at present 43 states enshrine secular principles in their constitutions, yet many of these have registered neither impressive economic performance nor political stability. Indeed, in some cases, such as in Bangladesh, secular commitments have entailed serious violations of freedom of religion. Significantly, in Europe, the cradle of secularism, only a few states (France, Kosovo) expressly declare themselves to be secular in their constitutions. Although Lithuania's constitution upholds secularism, it only does so with reference to education (Article 40).

The Constitution of the United States, while not explicitly declaring the state secular, nevertheless enshrines this principle in its First Amendment, which curiously enough is conjoined to a clause protecting religious freedom (hence demonstrating a close conceptual link between the religious and the secular). The First Amendment states that "Congress shall make no law respecting an establishment of religion, or prohibiting the free exercise thereof." The two parts of the clause, known as the "Establishment Clause" and the "Free Exercise Clause" respectively, are designed to render the state impartial in religious matters. However, this in turn necessitates a clear distinction between the "religious" and the "secular" and, accordingly, an exclusive privilege on the courts to define "religion". Given the porous boundaries between the two concepts, little surprise then that the application of the test for such a distinction, known as the 'Lemon test' (after the case, Lemon v Kurtzman [1971]), has been fraught with ambiguities.

Those provisions within the constitutions of Muslim countries that grant Islam a favoured position may - and, indeed, have been - interpreted pejoratively, as relics of identity politics and as potentially discriminatory towards religious minorities. Also, they have been thought of as an instance of "Islamisation from above."

From within the Muslim community, such clauses have been criticised as affording the state the opportunity to press its own version of Islam on the people. 
This has been the logic for many critics of constitutionalised Islam. Indeed, renowned Islamic legal scholar, Abdullahi al-Naim, has argued that one needs a secular state to be an authentic Muslim. Yet the judicial practice of multiple jurisdictions reveals this problem to be not uniquely Islamic. Even in the most secular jurisdictions, constitutions maintain a minimum threshold for protecting freedom of religion, thereby conferring on the courts the exclusive privilege of defining, delimiting and determining what religion is. Several cases in Malaysia have seen the Federal Court pronounce judgments on the nature of Islam, albeit not without consulting the views of experts on Islamic law. In Meor Atiqurrahman $v$ Fatimah Sihi (2006), the court declared that wearing a turban was not an integral part of Islam. In Hajah Halimatussaadiah v Public Services Commission (1994), the Supreme Court held that the purdah (face veil) is likewise not compulsory in Islam. The court reached these judgements without the need to resort to Article 3 , declaring Islam to be the religion of the Federation, even though this provision exists. The High Court in Meor did make mention of this Article, but this point was not taken up by the Court of Appeal and the Federal Court.

In some instances, the constitutional incorporation of Islamic law into state law marked a means by which Shariah could be regulated and reformed. For instance, the Supreme Constitutional Court of Egypt, notwithstanding Article 2, held that the state could use ijtihad unrestrained by the traditional methods of Islamic jurisprudence.

When they were originally adopted, many of the constitutions examined here had 'non-constitutionalist' motives for incorporating a provision on Islam. Often the move was initiated by the ruling elite, in part as a means of resolving crises, but also to consolidate power. The first such constitution was introduced in 1867, in Tunisia. Decades later, the same script was re-enacted as post-conflict states concurrently saw constitutions as peace compacts, instruments of conflict resolution and a basic framework for governance.

The popularity of Islamic references in constitutions reflects a deeply embedded social and cultural structure that defines the relationship between law, community and authority. As Muslim societies are exposed to a host of different external influences, constitutional law becomes a mediating point.

In conclusion, this viewpoint demonstrates that the nationalisation of Islamic law - when Islam has been constitutionalised and interpreted within the scheme of national laws - risks forsaking the unity and methodological coherence of Islam. In that context, there is a need for common global cooperation between Muslim states, to share experiences and knowledge, as well as possible common standards, such as for scholars, specialists or professionals who have to regularly testify in court as expert witnesses on Islamic matters. This is an opportunity 
to foster greater dialogue and legal engagement between the Islamic world and others.

\section{Notes}

* Tengku Ahmad Hazri is Research Fellow at IAIS Malaysia. He may be reached at ahmhazri@iais.org.my. 